\title{
Pengaruh Pendekatan Somatis Auditori Visual Intelektual (SAVI) terhadap Peningkatan Kemampuan Koneksi Matematis Siswa SMA
}

\author{
Ari Septian*, Citra Laila Ramadhanty, Puji Rachmawati \\ Pendidikan Matematika, Universitas Suryakancana, Indonesia \\ *ariseptian@unsur.ac.id
}

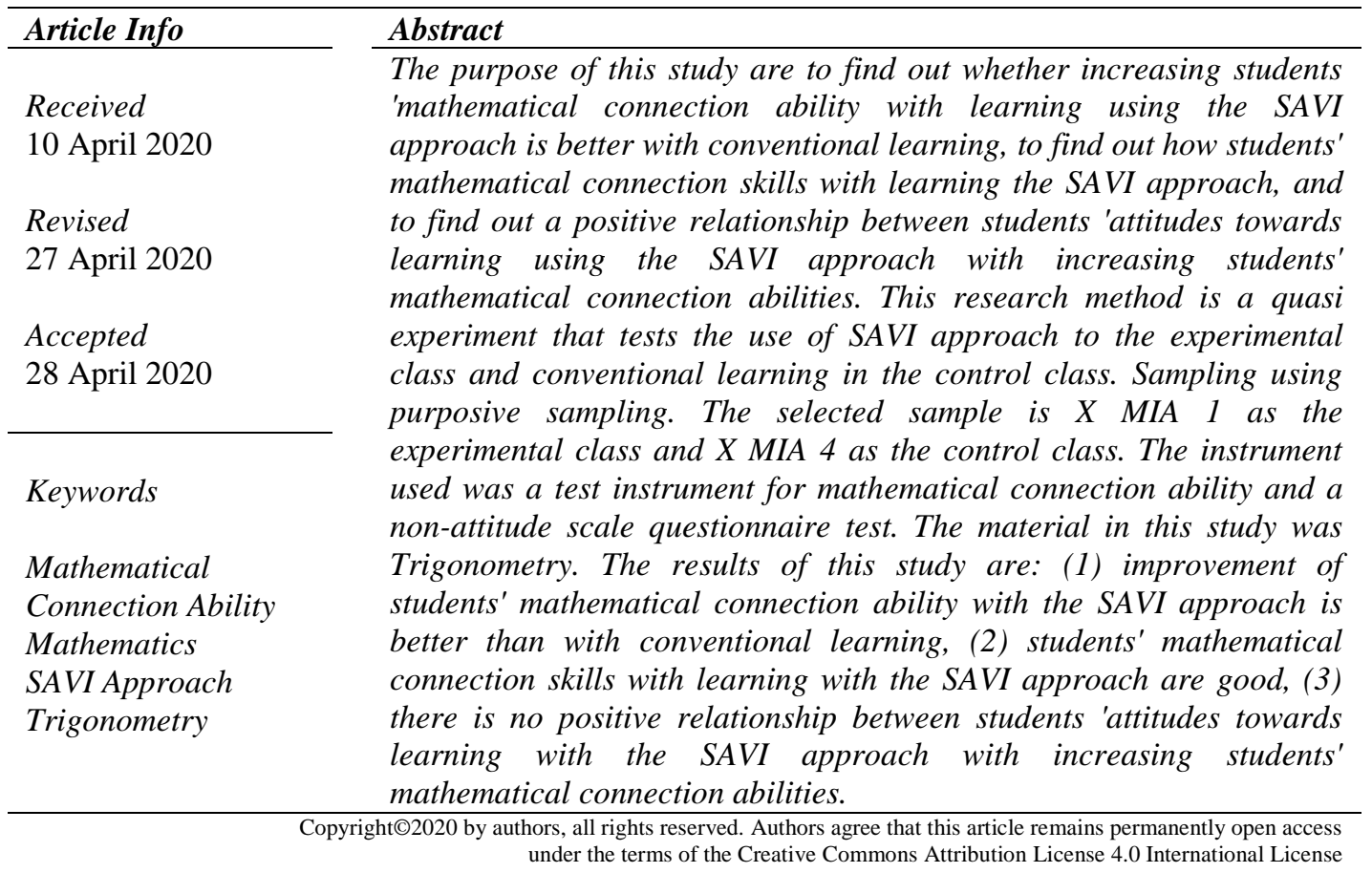

How to Cite:

Septian, A., Ramadhanty, C. L., \& Rachmawati, P. (2020). Pengaruh Pendekatan Somatis Auditori Visual Intelektual (SAVI) terhadap Peningkatan Kemampuan Koneksi Matematis Siswa SMA. Journal of Instructional Mathematics, 1(1), 1-10.

\section{PENDAHULUAN}

Salah satu proses pembelajaran yang penting adalah pembelajaran matematika, karena matematika merupakan salah satu ilmu dasar (basic science), ratu dari semua ilmu dan bisa dikatakan ilmu yang abstrak dan membutuhkan telaahan atau pengkajian lebih dalam. Heruman (dalam Widodo \& Kartikasari, 2017) menyatakan bahwa konsep yang abstrak harus dipahami dan segera diberi penguatan, supaya mengendap dan bertahan lama dalam memori, implikasinya akan melekat dalam pola pikir dan pola tindakannya". Oleh karena itu, perlu strategi yang mumpuni dari tenaga pengajar atau guru supaya pembelajaran matematika dapat berkesan dan menjadi pelajaran yang sangat disenangi oleh siswa, juga dapat meningkatkan dan mengembangkan kemampuan yang ada (Maskur dkk., 2020).

NCTM (2000) merekomendasikan 5 kompetensi atau kemampuan standar matematika yang wajib dimiliki siswa yakni kemampuan pemecahan masalah 
(problem solving), kemampuan penalaran dan pembuktian (reasoning and proof), kemampuan komunikasi (communication), kemampuan koneksi (connections), dan kemampuan representasi (representations). Oleh karena itu, mengacu pada lima standar kemampuan NCTM tersebut, pada penelitian ini digunakan salah satu standar kemampuan dasar matematika yaitu kemampuan koneksi matematis.

Kemampuan koneksi matematis merupakan hal yang penting untuk dikuasai oleh siswa (Septian \& Rizkiandi, 2017; Siagian \& Sembiring, 2018). Hal yang dapat dilakukan untuk bisa menguasai kemampuan koneksi matematis adalah siswa mampu mengaitkan ide matematika dengan pemahaman antar topik dalam matematika. Selain itu juga, didukung oleh Bruner (dalam Ruseffendi, 2006) bahwa dalam bidang studi matematika, suatu konsep itu berhubungan dengan konsep lainnya, contohnya antara suatu dalil dengan dalil yang lain, antara suatu teori dengan teori lain, antara suatu topik dengan topik lainnya, dan antar cabang matematika.

Namun, berdasarkan hasil observasi sebelum penelitian di sekolah, kemampuan koneksi matematis tersebut masih rendah. Kemampuan siswa dalam melakukan koneksi antar topik matematika menjadi kemampuan terendah, dilanjutkan koneksi dengan ilmu yang lain diluar matematika dan tingkat tertinggi terdapat pada kemampuan koneksi dengan dunia nyata.

Matematika adalah aktivitas manusia (human activity) dan oleh karenanya matematika dapat kita pelajari dengan baik bila disertai dengan mengerjakannya (doing mathematics). Sehingga, pembelajaran matematika hendaknya disertai dengan berbagai aktivitas siswa.

Penelitian Dr. Vernon Magnesen dari Universitas Texas tentang ingatan, memberikan gambaran yang dapat diilustrasikan sebagai berikut (Meier, 2000).

\begin{tabular}{|c|c|}
\hline Membaca & \\
\hline Mendengarl & $0 \%)$ \\
\hline Melihat & $(40 \%)$ \\
\hline Mengucap & $(50 \%)$ \\
\hline Melakukan & $(60 \%)$ \\
\hline $\begin{array}{l}\text { Melihat,Me } \\
\text { Mendengar }\end{array}$ & lakukan \\
\hline
\end{tabular}

Gambar 1. Ilustrasi tentang Ingatan

Berdasarkan Gambar 1, menunjukkan bahwa pengetahuan yang dapat diingat seseorang bergantung pada indera yang digunakan untuk memperoleh pengetahuan tersebut, baik secara visual, auditori, somatis, maupun kombinasi ketiganya.

Pembelajaran dengan pendekatan SAVI adalah pembelajaran melalui kombinasi pergerakan fisik dan aktifitas intelektual atau berpikir serta melibatkan semua indera yang dalam pembelajaran (Ulvah \& Afriansyah, 2016; Siagian \& Sembiring, 2018). Pendekatan SAVI memiliki kesesuaian karakter dengan pembelajaran yang ingin mengangkat kemampuan koneksi matematis siswa. Kegiatan belajar dengan pendekatan SAVI dapat lebih optimal karena menggunakan segenap indera siswa. Siswa akan makin terasah kemampuan matematikanya ketika mereka menggunakan segenap inderanya, sehingga mampu menghubungkan antara topik yang dipelajari dengan topik lain, materi pelajaran 
matematika dengan pelajaran lain diluar matematika, serta menghubungkan matematika dalam kehidupan sehari-hari.

Berdasarkan latar belakang masalah, maka rumusan permasalahan tersebut dijabarkan sebagai berikut: (1) apakah peningkatan kemampuan koneksi matematis siswa dengan pembelajaran metode SAVI lebih baik daripada dengan model pembelajaran konvensional ? (2) Bagaimana kemampuan koneksi matematis siswa dengan metode SAVI? (3) Apakah Terdapat Hubungan yang Positif Antara Sikap Siswa Terhadap Pembelajaran Metode SAVI dengan peningkatan kemampuan koneksi matematis siswa?

\title{
Pendekatan SAVI
}

Pembelajaran dengan menggunakan pendekatan SAVI adalah pembelajaran yang menggabungkan gerakan fisik dengan aktivitas intelektual dan penggunaan semua indera yang dapat berpengaruh besar pada pembelajaran. Adapun Unsur-unsur SAVI menurut Meier (2000) antara lain:

\author{
$\mathrm{S} \rightarrow$ Somatis (Learning by Doing) \\ Belajar Dengan Gerak dan Berbuat \\ $\mathrm{A} \rightarrow$ Auditori (Learning by Hearing) \\ Belajar Dengan Berbicara dan Mendengarkan \\ $\mathrm{V} \rightarrow$ Visual (Learning by Seeing) \\ Belajar Dengan Mengamati \\ $\mathrm{I} \rightarrow$ Intelektual (Learning by Thinking) \\ Belajar Dengan Berpikir dan Memecahkan Masalah
}

Alasan yang mendasar sehingga perlunya diterapkan pendekatan SAVI dalam kegiatan belajar sehari-hari, khususnya belajar matematika antara lain dapat menciptakan lingkungan yang positif (lingkungan yang tenang dan menggugah semangat), keterlibatan siswa sepenuhnya (aktif dan kreatif), adanya kerjasama di antara siswa, menggunakan metode mengajar yang bervariasi, dapat menggunakan pembelajaran kontekstual, serta dapat menggunakan alat peraga (Meier, 2000; Ulvah \& Afriansyah, 2016).

Pembelajaran SAVI merupakan model pembelajaran yang melibatkan siswa untuk mengikuti proses pembelajaran secara aktif. Aktif memecahkan masalah dalam kelompok, mendengarkan apa yang dijelaskan guru dan teman-temannya, dan berani untuk menjelaskan apa yang diketahuinya (Ulvah \& Afriansyah, 2016).

\section{Koneksi Matematis}

Sumarmo memaparkan bahwa koneksi matematis merupakan dua kata yang berasal dari Bahasa Inggris yaitu Mathematical Connection oleh NCTM sehingga dijadikan standar kurikulum pembelajaran matematika sekolah dasar dan menengah (Septian \& Komala, 2019; Warih dkk., 2016). Sedangkan menurut Ruspiani (dalam Permana \& Sumarmo, 2007) kemampuan koneksi matematis merupakan kemampuan menghubungkan antara konsep matematika, baik antara konsep di matematika itu sendiri maupun menghubungkan konsep matematika dengan konsep dalam bidang lainnya.

Selain itu, kemampuan koneksi matematis juga merupakan kemampuan untuk mengaitkan konsep, prinsip atau prosedur yang terdapat di dalam matematika 
dengan matematika itu sendiri, matematika dengan bidang ilmu lain, dan matematika dengan kehidupan sehari-hari (Badjeber \& Fatimah, 2015; Septian \& Komala, 2019; Septian \& Rizkiandi, 2017).

Koneksi dalam matematika merupakan hubungan dari ide-ide atau gagasan yang digunakan untuk merumuskan dan menguji topik-topik matematika secara deduktif. Pada penelitian ini, Indikator kemampuan koneksi matematis siswa yang digunkan yaitu (1) Mencari dan memahami hubungan berbagai representasi konsep dan prosedur. (2) Menggunakan matematika dalam bidang studi lain atau kehidupan sehari-hari. (3) Memahami representasi ekuivalen konsep atau prosedur yang sama. (4) Mencari koneksi satu prosedur ke prosedur lain dalam representasi yang ekuivalen. (5) Menggunakan koneksi antar topik matematika, dan antara topik matematika dengan topik lain.

\section{METODE PENELITIAN}

Metode penelitian yang digunakan dalam penelitian ini adalah quasi eksperimen. Sedangkan desain yang digunakan dalam penelitian ini adalah desain penelitian nonequivalent control group design. Populasi penelitian ini adalah siswa kelas X MIA SMA Negeri 2 Cianjur semester genap tahun ajaran 2016/2017. Teknik sampling yang digunakan dalam penelitian ini adalah purposive sampling, dengan sampel penelitian yang terdiri dari dua kelas yaitu kelas X MIA 1 dan kelas X MIA 4. Selanjutnya, dari kelas tersebut, satu kelas akan diberikan treatment sebagai kelas eksperimen (X MIA 1) dengan pendekatan SAVI berjumlah 35 orang siswa, dan satu kelas lainnya sebagai kelas kontrol (X MIA 4) dengan menggunakan model pembelajaran konvensional berjumlah 32 orang.

Untuk mengetahui kemampuan koneksi matematis siswa pada kedua kelas diberikan tes kemampuan koneksi matematis yang terdiri dari 6 soal tes tertulis dalam bentuk uraian.

Skor pretest dan posttest dilihat dan dihitung perbedaan hasilnya dengan menggunakan pedoman penskoran rubrik tes kemampuan koneksi matematis . Adapun pedoman penskoran dalam tes kemampuan koneksi matematis disajikan pada Tabel 1.

Tabel 1. Pedoman Penskoran Rubik Tes Kemampuan Koneksi Matematika

\begin{tabular}{lc}
\hline \multicolumn{3}{l}{ Reaksi Terhadap Masalah/Soal } & Skor \\
\hline Tidak ada jawaban & 0 \\
\hline $\begin{array}{l}\text { Jawaban hampir tidak mirip/ sesuai dengan pertanyaan, persoalaan } \\
\text { atau dengan masalah }\end{array}$ & 1 \\
\hline $\begin{array}{l}\text { Jawaban ada beberapa yang mirip / sesuai dengan pertanyaan, } \\
\text { persoalaan atau dengan masalah tetapi koneksinya tidak jelas }\end{array}$ & 2 \\
\hline $\begin{array}{l}\text { Jawaban ada beberapa yang mirip / sesuai dengan pertanyaan, } \\
\text { persoalaan atau dengan masalah tetapi koneksinya jelas tetapi kurang }\end{array}$ & 3 \\
lengkap & \\
\hline $\begin{array}{l}\text { Jawaban mirip / sesuai dengan pertanyaan, persoalaan atau dengan } \\
\text { masalah tetapi tidak lengkap }\end{array}$ & 4 \\
\hline $\begin{array}{l}\text { Jawaban mirip / sesuai dengan pertanyaan, persoalaan atau dengan } \\
\text { masalah secara lengkap }\end{array}$ & 5 \\
\hline
\end{tabular}


HASIL DAN PEMBAHASAN

Peningkatan Kemampuan Koneksi Matematis Siswa Setelah Mendapatkan Pembelajaran dengan Metode SAVI

Analisis data skor awal koneksi matematis siswa diawali dengan menganalisis apakah sampel berasal dari sampel berdistribusi normal atau tidak. Berdasarkan hasil pengolahan data, diperoleh hasil analisis data pretest menunjukkan bahwa kelas eksperimen berdistribusi normal sedangkan kelas kontrol berdistribusi tidak normal. Hal ini bisa dilihat dari nilai signifikansi, kelas eksperimen memiliki nilai signifikansi sebesar $0.288>0.05$ sedangkan kelas kontrol memiliki nilai signifikansi sebesar $0.001<0.05$ yang artinya kelas kontrol berasal dari sampel yang berdistribusi tidak normal.

Terdapat salah satu data pretest berdistribusi tidak normal yakni data pretest kelas kontrol, maka pengolahan data dilanjutkan dengan Uji Nonparametric Mann-Whitney. Hasil pengolahan data dengan Nonparametric Mann-Whitney disajikan pada Tabel 2.

Tabel 2. Hasil Uji Mann Whitney Data Pretest

\begin{tabular}{cc}
\hline Asymp. Sig. (2-tailed) & Keterangan \\
\hline 0,002 & $\mathrm{H}_{0}$ ditolak \\
\hline
\end{tabular}

Berdasarkan Tabel 2, diperoleh nilai signifikansi 0,002. Nilai tersebut lebih kecil dari 0,05 , maka $\mathrm{H}_{0}$ ditolak atau $\mathrm{H}_{1}$ diterima. Dengan demikian, dapat disimpulkan bahwa kelas eksperimen dan kelas kontrol mempunyai kemampuan awal koneksi matematis yang berbeda. Setelah mengetahui kemampuan awal koneksi matematis siswa, selanjutnya dilakukan uji statistik deskriptif dan inferensial untuk mengetahui peningkatan kemampuan koneksi matematis siswa, berikut adalah hasil uji statistik deskriptif data $N$-Gain.

Berdasarkan hasil pengolahan data, diperoleh hasil analisis $N$-Gain menunjukkan bahwa kelas eksperimen dan kelas kontrol berasal dari populasi yang berdistribusi tidak normal. Hal ini bisa dilihat dari nilai signifikansi kedua kelas yang sama yakni 0.000. Karena kedua kelas berdistribusi tidak normal, maka pengolahan dilanjutkan dengan Uji Mann-Whitney.

Tabel 3. Hasil Uji Mann Whitney Data N-Gain

\begin{tabular}{cc}
\hline Asymp. Sig. (2-tailed) & Keterangan \\
\hline 0,000 & $\mathrm{H}_{0}$ ditolak \\
\hline
\end{tabular}

Berdasarkan Tabel 3, hasil analisis data N-Gain menunjukkan bahwa peningkatan kemampuan koneksi matematis siswa kelas eksperimen lebih baik dari kelas kontrol. Hal ini bisa dilihat dari hasil nilai signifikansinya kurang dari 0.05 yakni sebesar 0.000. Dari hasil tersebut, dapat disimpulkan bahwa peningkatan kemampuan koneksi matematis siswa kelas eksperimen lebih baik dari kelas kontrol. Sejalan dengan penelitian sebelumnya, peningkatan kemampuan koneksi matematis siswa yang menggunakan metode SAVI lebih baik daripada siswa yang melakukan pembelajaran konvensional (Siagian \& Sembiring, 2018; Agustina, Yurniwati \& Zulela, 2019). 


\section{Bagaimana Kemampuan Koneksi Matematis Siswa dengan Metode SAVI}

Penelitian ini dilakukan terhadap dua kelas, yakni kelas eksperimen dan kelas kontrol yang diberikan soal trigonometri untuk mengetahui kemampuan koneksi matematis siswa. Kemampuan koneksi matematis siswa dengan metode SAVI yaitu baik. Hasil penelitian di analisis secara deskriptif, untuk menjelaskan kemampuan dari masing-masing siswa dalam kemampuan koneksi matematis. Hasil Pekerjaan siswa pada soal-soal yang diberikan, diantaranya:

Soal nomor 1 ini menguji siswa untuk menemukan kebenaran suatu pernyataan dengan memahami konsep perbandingan trigonometri antar kuadran. Kemampuan koneksi siswa untuk menyatakan kebenaran suatu pernyataan dengan memahami representasi ekuivalen suatu konsep, proses, atau prosedur matematis diuji dengan pernyataan, karena pada umumnya siswa belum terbiasa dengan soal-soal seperti ini.

$$
\begin{aligned}
& \text { 1. a) Tidak karna cscx memiliki tanda posity di. } \\
& \text { kuadran I \& II saja sedanglean tan } x \text { memilici } \\
& \text { tanda posity hanya di kuadran I \& III } \\
& \text { b) Tidak karena di lcuadran II hanya nilai... sin } \\
& \text { yang bernilai positic. } \\
& \text { c) Benar karena cos y terletale ds luadran II } \\
& \begin{array}{l}
\text { dan bernilai negatef. sedanglean sinx di lcuadran } \\
\text { I bernilai positif }
\end{array}
\end{aligned}
$$

Gambar 2. Contoh Jawaban Nomor 1

Pada Gambar 2, dapat disimpulkan siswa sudah mampu menemukan kebenaran suatu pernyataan dengan memahami konsep perbandingan trigonometri antar kuadran.Hal ini juga menunjukkan bahwa kemampuan koneksi siswa untuk menyatakan kebenaran suatu pernyataan dengan memahami representasi ekuivalen suatu konsep, proses, atau prosedur matematis diuji dengan pernyataan sudah baik.

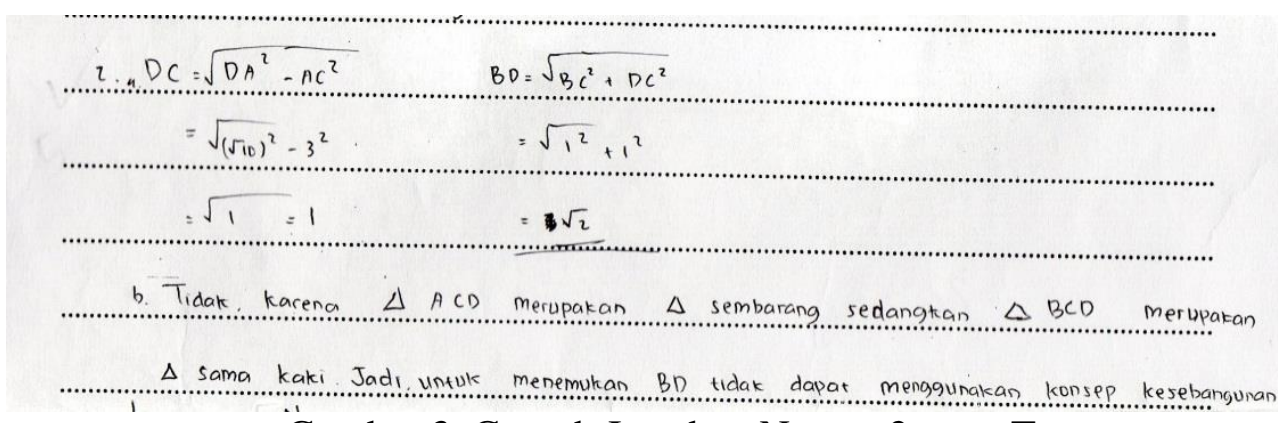

Gambar 3. Contoh Jawaban Nomor 2 yang Tepat

Berdasarkan Gambar 3, untuk bagian a siswa sudah mampu mencari panjang sisi segitiga siku-siku namun tidak dengan menggunakan konsep trigonometri, sedangkan untuk bagian $\mathrm{b}$ siswa belum bisa menjawab dengan benar. Ada 
beberapa siswa yang sudah dapat memberikan jawaban yang sesuai. Indikator kemampuan koneksi pada soal nomor 3 adalah menentukan besar sudut dan letak kuadran dari sudut tersebut dalam penerapan trigonometri di bidang ilmu lain sudah baik.

\begin{tabular}{|c|c|c|c|c|c|c|c|c|c|c|c|c|c|c|c|}
\hline \multicolumn{16}{|c|}{$y=\sin 2 x$} \\
\hline$x$ & $0^{\circ}$ & $30^{\circ}$ & $45^{\circ}$ & $60^{\circ}$ & $90^{\circ}$ & $120^{\circ}$ & $135^{\circ}$ & $150^{\circ}$ & $180^{\circ}$ & $210^{\circ}$ & $225^{\circ}$ & $240^{\circ}$ & $270^{\circ}$ & $300^{\circ}$ & \begin{tabular}{ll|l}
$315^{\circ}$ & $330^{\circ}$
\end{tabular} \\
\hline$y / f(x)$ & 0 & $\frac{1}{2}$ & $\mid x_{2} 1$ & $\frac{1}{2} \sqrt{3}$ & 0 & $\frac{1}{2} \sqrt{3}$ & -1 & $-\frac{1}{2} \sqrt{3}$ & 0 & $\frac{1}{2} \sqrt{3}$ & 1 & $2^{n}$ & 0 & $\frac{1}{2} \sqrt{1}$ & $-1 \mid \frac{1}{\varepsilon} \sqrt{3}$ \\
\hline
\end{tabular}

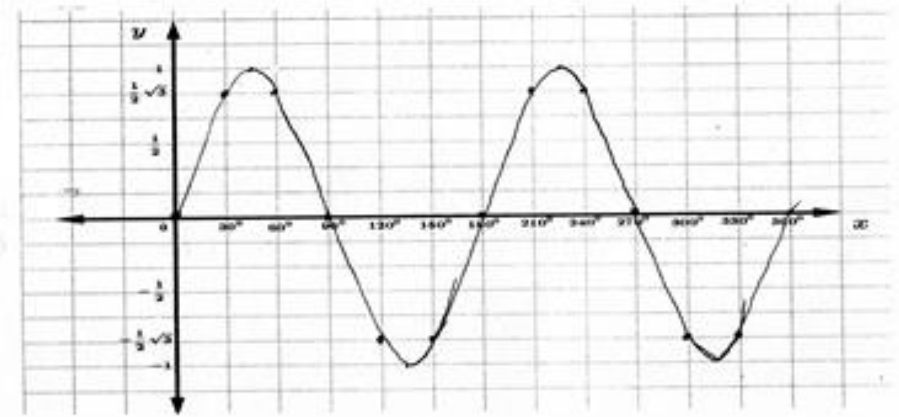

Gambar 4. Contoh Jawaban Nomor 4

Pada Gambar 4, indikator kemampuan koneksi matematis yang digunakan adalah membuat grafik fungsi trigonometri dengan cara memahami representasi ekuivalen suatu konsep, proses, atau prosedur matematis. Siswa sudah dapat menghubungkan/mengkoneksikan antara persamaan trigonometri dengan grafik.

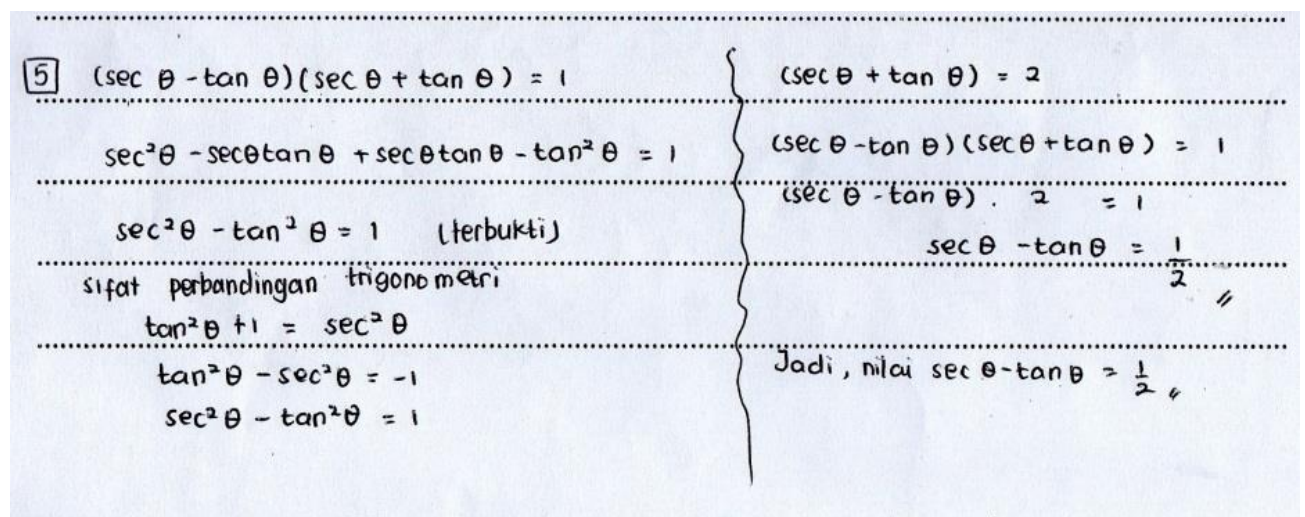

Gambar 5. Contoh Jawaban Nomor 5

Pada Gambar 5, indikator kemampuan koneksi matematis yang digunakan adalah membuktikan sifat trigonometri dengan cara mencari hubungan berbagai representasi konsep trigonometri dan memahami hubungan antar topik matematika. Siswa sudah dapat mencari hubungan berbagai representasi konsep trigonometri dan memahami hubungan antar topik matematika.

Pada Gambar 6, indikator kemampuan koneksi matematis yang digunakan adalah mencari sisi segitiga siku-siku dengan menggunakan perbandingan trigonometri, dalam penerapan trigonometri di kehidupan sehari-hari. Gambar tersebut menunjukkan bahwa siswa sudah mampu menjawab pertanyaan meskipun masih kurang lengkap. Kesalahan yang terjadi umumnya pada soal nomor 6 ini adalah siswa tidak teliti dalam menentukan panjang sisi depan dari sudut yang telah diketahui. 


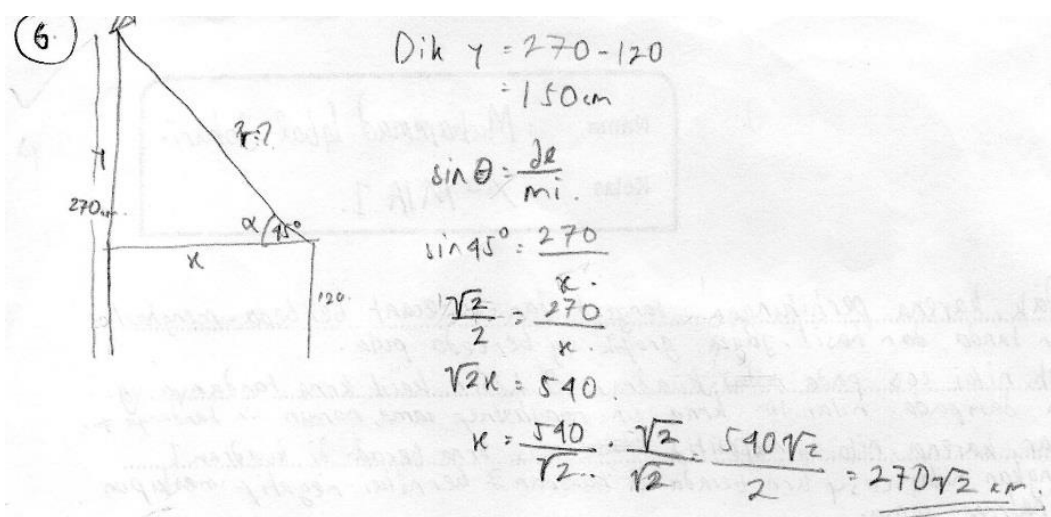

Gambar 6. Contoh Jawaban Nomor 6

Pada soal nomor 5, indikator kemampuan koneksi matematis yang digunakan adalah membuktikan sifat trigonometri dengan cara mencari hubungan berbagai representasi konsep trrigonometri dan memahamii hubungan antar topic matematika. Adapun contoh jawaban siswa seperti pada berikut ini.

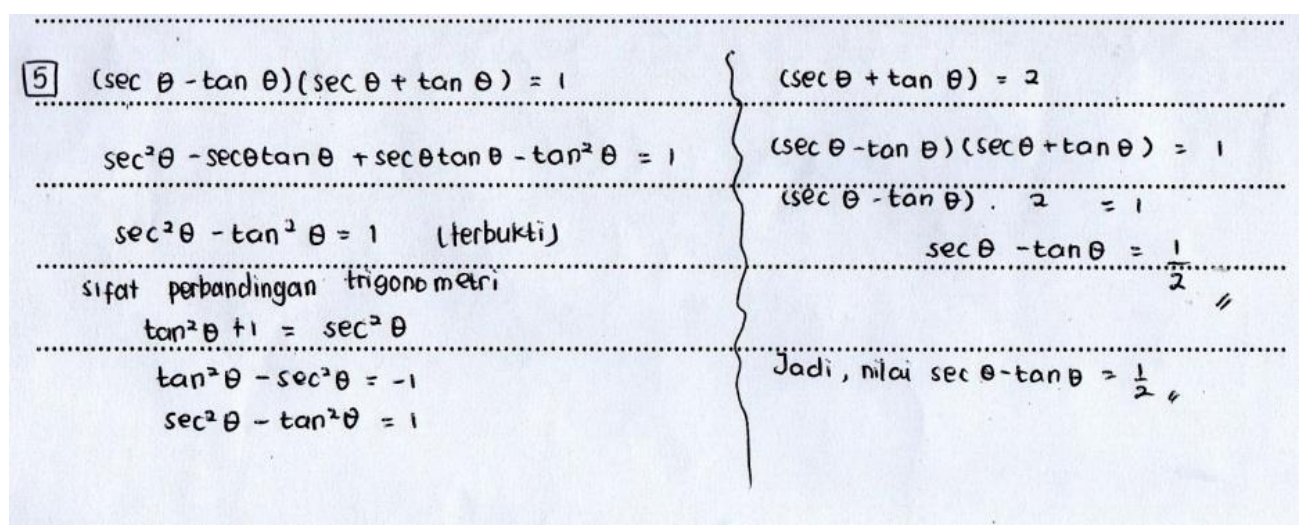

Gambar 5. Contoh Jawaban Nomor 5

Pada soal nomor 6, indikator kemampuan koneksi matematis yang digunakan adalah mencari sisi segitiga siku-siku dengan menggunakan perbandingan trigonometri, dalam penerapan trigonometri di kehidupan sehari-hari. Adapun contoh jawaban siswa seperti pada gambar berikut ini.

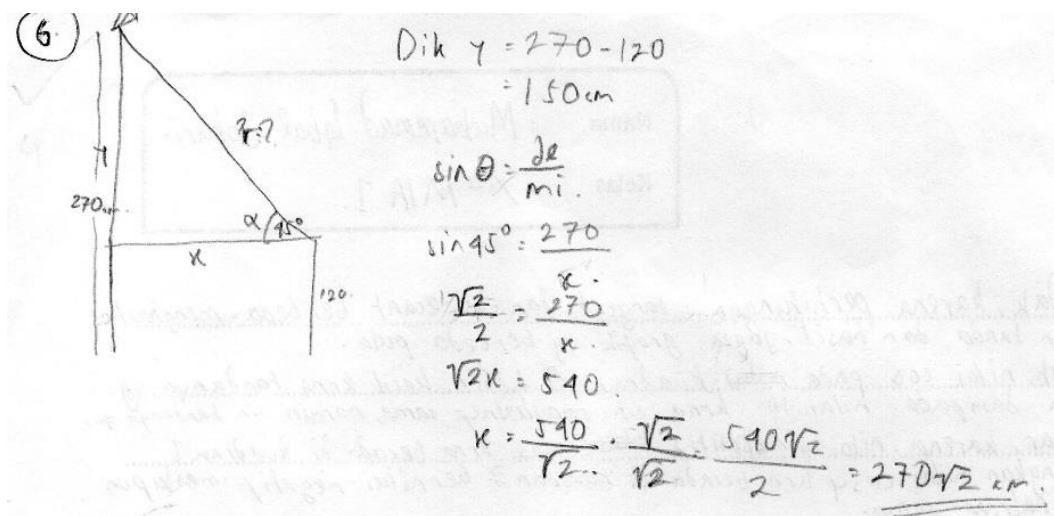

Gambar 6. Contoh Jawaban Nomor 6 
Gambar tersebut menunjukkan bahwa siswa sudah mampu menjawab pertanyaan meskipun masih kurang lengkap. Kesalahan yang terjadi umumnya pada soal nomor 6 ini adalah siswa tidak teliti dalam menentukan panang sisi depan dari sudut yang telah diketahui.

\section{Hubungan antara Sikap Siswa dalam Pembelajaran Matematika dengan Metode SAVI dengan Peningkatan Kemampuan Koneksi Matematis Siswa}

Berdasarkan data yang diperoleh, nilai koefisien korelasi sebesar 0.131, artinya korelasi atau hubungan antara sikap siswa terhadap pembelajaran SAVI dengan peningkatan kemampuan koneksi matematis siswa sangat lemah (hampir tidak ada hubungan). Angka korelasi menunjukkan nilai positif artinya hubungan yang terjadi searah, jika nilai sikap siswa meningkat satu satuan maka nilai indeks gain akan meningkat sebesar 0.131 dan sebaliknya jika nilai indeks gain meningkat satu satuan maka nilai sikap siswa meningkat sebesar 0.131 .

Dari data di atas, didapat nilai signifikansi sebesar 0.453. Karena nilai signifikansi tersebut lebih besar dari 0.05 maka tidak terdapat hubungan yang positif antara sikap siswa terhadap peningkatan kemampuan koneksi matematis siswa dengan pembelajaran menggunakan pendekatan SAVI.

Hasil analisis data indeks gain dan sikap siswa didapat, terdapat siswa yang memiliki nilai sikap sebesar 5.8 memiliki nilai indeks gain sebesar 10.00, siswa yang memiliki nilai sikap sebesar 6.4 memiliki nilai indeks gain sebesar 10.00 dan siswa yang memiliki nilai sikap sebesar 8.5 memiliki nilai indeks gain sebesar 10.00. Hal tersebut menunjukkan bahwa tidak terdapat hubungan yang positif antara sikap siswa terhadap pembelajaran SAVI dengan peningkatan kemampuan koneksi matematis. Padahal Siagian \& Sembiring (2018) mengutip bahwa pendekatan SAVI memberikan peluang lebih besar bagi siswa dalam mengembangkan kemampuan matematik siswa di mana seluruh alat indera dilibatkan dalam proses pembelajaran. Misalnya, unsur somatisnya dikembangkan agar memiliki sikap kreatif dan berjiwa berani mengemukakan pendapatnya.

\section{KESIMPULAN}

Berdasarkan hasil penelitian yang berjudul "Pengaruh Pendekatan Somatis Auditori Visual Intelektual (SAVI) Terhadap Peningkatan Kemampuan Koneksi Matematis Siswa SMA" di SMA Negeri 2 Cianjur, diperoleh kesimpulan sebagai berikut: (1) Peningkatan kemampuan koneksi matematis siswa dengan Pembelajaran Matematika menggunakan pendekatan SAVI lebih baik daripada dengan pembelajaran konvensional; (2) Berdasarkan hasil angket, siswa bersikap positif terhadap pembelajaran matematika dengan menggunakan pendekatan SAVI; (3) Tidak terdapat hubungan positif antar sikap siswa dalam pembelajaran Matematika menggunakan pendekatan SAVI dengan peningkatan kemampuan koneksi matematis siswa.

\section{REFERENSI}

Agustina, F. N., Yurniwati., \& Zulela, M. S. (2019). Pengaruh Model Pembelajaran SAVI (Somatis, Audiotory, Visualization, Intellectual) terhadap Kemampuan Koneksi Matematis Siswa di Kelas V Sekolah 
Dasar. Dinamika Matematika Sekolah Dasar, 1(1), 1-11.

Badjeber, R., \& Fatimah, S. (2015). Peningkatan Kemampuan Koneksi Matematis Siswa SMP melalui Pembelajaran Inkuiri Model Alberta. Jurnal Pengajaran MIPA, 20(1), 18-26. https://doi.org/ 10.18269/jpmipa.v20i1.557

Maskur, R., Sumarno., Rahmawati, Y., Pradana, K., Syazali, M., Septian, A., \& Palupi, E. K. (2020). The effectiveness of problem based learning and aptitude treatment interaction in improving mathematical creative thinking skills on curriculum 2013. European Journal of Educational Research, 9(1), 375-383. https://doi.org/10.12973/eu-jer.9.1.375

Meier, D. (2000). The Accelerated Learning Handbook A Creative Guide to Designing and Delivering Faster, More Effective Training Programs. USA: McGraw-Hill Companies, Inc.

NCTM. (2000). Principles and Standards for School Mathematics. Reston, Va: NCTM

Permana, Y., \& Sumarmo, U. (2007). Mengembangkan Kemampuan Penalaran dan Koneksi Matematik Siswa SMA melalui Pembelajaran Berbasis Masalah. Educationist, 1(2), 116-123.

Ruseffendi, E. T. (2006). Pengantar kepada Membantu Guru Mengembangkan Kompetensinya dalam Pengajaran Matematika untuk Meningkatkan CBSA. Bandung: Tarsito.

Septian, A., \& Komala, E. (2019). Kemampuan Koneksi Matematik Dan Motivasi Belajar Siswa dengan Mengunakan Model Problem-Based Learning (PBL) Berbantuan Geogebra di SMP. Prisma, 8(1), 1-13. https://doi.org/ 10.35194/jp.v8i1.438

Septian, A., \& Rizkiandi, R. (2017). Penerapan Model Problem Based Learning (PBL) terhadap Peningkatan Kemampuan Berpikir Kreatif Matematis Siswa. Prisma, 6(1), 1-8. https://doi.org/10.35194/jp.v6i1.22

Siagian, M. D., \& Sembiring, M. B. (2018). Perbedaan Peningkatan Kemampuan Koneksi Matematis Siswa ditinjau melalui Aplikasi Pendekatan Pembelajaran SAVI Berbasis Lingkungan dan Pembelajaran Ekspositori. MES: Journal of Mathematics Education and Science, 4(1), 5965. https://doi.org/10.30743/mes.v4i1.870

Ulvah, S., \& Afriansyah, E. A. (2016). Kemampuan pemecahan masalah matematis siswa ditinjau melalui model pembelajaran SAVI dan konvensional. Jurnal Riset Pendidikan, 2(2), 142-153.

Warih, P. D., Parta, I. N., \& Rahardjo, S. (2016). Analisis Kemampuan Koneksi Matematis Siswa Kelas VIII pada Materi Teorema Pythagoras. Prosiding Konferensi Nasional Penelitian Matematika dan Pembelajarannya I, 377384.

Widodo, S., \& Kartikasari, K. (2017). Pembelajaran Pemecahan Masalah Matematis Siswa Sekolah Dasar dengan Model Creative Problem Solving (CPS). Prisma, 6(1), 57-65. https://doi.org/10.35194/jp.v6i1.28 